\title{
Biogas production of Chicken Manure by Two-stage fermentation process
}

\author{
Xin Yuan Liu, Jing Jing Wang, Jia Min Nie, Nan Wu, Fang Yang, Ren Jie Yang \\ College of Engineering and Technology, Tianjin Agricultural University, Tianjin 300384, China
}

\begin{abstract}
This paper performs a batch experiment for pre-acidification treatment and methane production from chicken manure by the two-stage anaerobic fermentation process. Results shows that the acetate was the main component in volatile fatty acids produced at the end of pre-acidification stage, accounting for $68 \%$ of the total amount. The daily biogas production experienced three peak period in methane production stage, and the methane content reached $60 \%$ in the second period and then slowly reduced to $44.5 \%$ in the third period. The cumulative methane production was fitted by modified Gompertz equation, and the kinetic parameters of the methane production potential, the maximum methane production rate and lag phase time were $345.2 \mathrm{ml}, 0.948 \mathrm{ml} / \mathrm{h}$ and $343.5 \mathrm{~h}$, respectively. The methane yield of $183 \mathrm{ml}-\mathrm{CH}_{4} / \mathrm{g}^{-} \mathrm{VS}_{\text {removed }}$ during the methane production stage and VS removal efficiency of $52.7 \%$ for the whole fermentation process were achieved.
\end{abstract}

\section{Introduction}

As the amount of the large scale livestock and poultry farms increased in China, the discharged manure increased accordingly and the environment pollution caused by manure became prominent gradually in recent years. Statistics suggested that the chemical oxygen demand (COD) and the ammonium nitrogen $\left(\mathrm{NH}_{4}{ }^{+}-\mathrm{N}\right)$ produced from livestock and poultry manure in China reached to 10.99 and 0.63 million ton, respectively, accounting for $45 \%$ and $25 \%$ of the summation discharged into environment nationwide, and also being equivalent to $95 \%$ and $78 \%$ of the summation produced by agricultural resources [1]. As one of the dominant manures in China, the chicken manure had the features of huge amount, complex component, high content of organic matters, and high concentration of nitrogen and phosphorus, etc. [2]. The centralized discharge of the chicken manure from large scale farms would directly get the surrounding soil, atmosphere and water polluted, and further bring down the local environment level in the rural area. However, the organic matters and nitrogen in chicken manure are the valuable biomass resource, and they could be reused and transferred into resources and energy materials by some recycle technologies. Anaerobic fermentation technology could produce biogas from the organic matters derived from manure by the metabolic activity of microorganisms, and it was recommended as the recycling method for manure treatment in China [3]. Besides, the $\mathrm{NH}_{4}{ }^{+} \mathrm{N}$ in manure could be released greatly under the degradation of protein-based substrates, which would be benefit for increasing the fertilizer efficiency in the agricultural reuse.
However, the high content of free ammonia (NH3, main part of total $\mathrm{NH}_{4}{ }^{+}-\mathrm{N}$ ) in the fermentation liquid would inhibit methanogens and reduce the methane production [4]. Among all kinds of livestock and poultry manure, chicken manure contains relatively high content of nitrogen as well as the low carbon to nitrogen ratio $(\mathrm{C} / \mathrm{N})$, which is more likely to cause severe inhibition effect as the fermentation substrate [5]. The simplest measure to reduce the reverse effects of $\mathrm{NH}_{4}{ }^{+}-\mathrm{N}$ on methanogens is diluting chicken manure with water by the application of wet anaerobic fermentation process. Two-stage fermentation process with pre-acidification stage and subsequence methane production stage was utilized in this study, and the component of volatile fatty acids (VFAs), methane yield and volatile solid (VS) removal efficiency were investigated to estimate the fermentation efficiency of chicken manure.

\section{Materials and Methods}

\subsection{Seed sludge}

The seed sludge was collected from sewage sludge digestion tank in Jingu wastewater treatment plant located in Tianjin, China. However, the seed sludge for pre-acidification was heat-treated at $100^{\circ} \mathrm{C}$ for $30 \mathrm{~min}$ to eliminate the methanogens and enrich acidate bacteria, and its VS/TS (total solid) was $44.9 \%$. The collected seed sludge with VS/TS of $49.5 \%$ was directly used as methane-producing seed sludge.

\subsection{Chicken Manure}

\footnotetext{
* Corresponding author: liuxinyuan11@163.com
} 
The chicken manure collected from household farms in the surrounding of west campus of Tianjin agricultural University located in Xiqing District of Tianjin, China. It was used as fermentation substrate and its main component was analyzed.

\subsection{Experimental conditions}

Batch experiments were conducted using $300 \mathrm{ml}$ serum bottles filled with $150 \mathrm{ml}$ of substrates. The substrate concentration was $10 \mathrm{~g}-\mathrm{VS} / \mathrm{l}$ in each bottle. Batch experiments were conducted in duplicate. The initial $\mathrm{pH}$ was 5.5 and the seed sludge for pre-acidification was $1.20 \mathrm{~g}$-VS. Both bottles were purged by nitrogen gas for $3 \mathrm{~min}$ and then sealed by rubber stoppers. The bottles were put in a shaker with rotating speed of $120 \mathrm{rpm}$ and the temperature of $37^{\circ} \mathrm{C}$. Three day later, the methaneproducing seed sludge with the VS weight of $0.8 \mathrm{~g}$ was added into each bottle. The $\mathrm{pH}$ of the substrate was adjusted to 7.0 and then the $\mathrm{K}_{2} \mathrm{HPO}_{4} / \mathrm{KH}_{2} \mathrm{PO}_{4}$ buffer solution ( $\mathrm{pH} 7.0$ ) was added. All the bottles were purged by nitrogen gas for 3 min again before sealing and then put in the incubator for methane fermentation at $37^{\circ} \mathrm{C}$. The produced gas and methane content was measured periodically.

\subsection{Analytical methods}

Production of biogas was measured by a glass syringe. Methane content in biogas produced in methane production stage were analyzed by a gas chromatograph (Clarus 680 PerkinElmer, USA) equipped with a flame ionization detector and a capillary column (Elite-5, $30 \mathrm{~m} \times 0.25 \mathrm{~mm} \times 0.25 \mu \mathrm{m})$. Nitrogen was used as the carrier gas at a flow rate of $2 \mathrm{ml} / \mathrm{min}$. The operation temperatures of the injection port, oven and detector were $200^{\circ} \mathrm{C}, 150^{\circ} \mathrm{C}$ and $250^{\circ} \mathrm{C}$, respectively. VFA including acetate, propionate, butyrate, $i$-butyrate and $i$ valerate in the mixed liquor were analyzed by another gas chromatograph (Agilent 7890B, USA) equipped with a flame ionization detector and a fused-silica capillary column $(\mathrm{HP}-5,30 \mathrm{~mm} \times 320 \mu \mathrm{m} \times 0.25 \mu \mathrm{m})$. Nitrogen was used as the carrier gas with a flow rate of $30 \mathrm{ml} / \mathrm{min}$ and the split ratio of $20: 1$. The temperature of injection port and detector were $250^{\circ} \mathrm{C}$ and $270^{\circ} \mathrm{C}$, respectively. The temperature program for oven was as following: $80^{\circ} \mathrm{C}$ for $1 \mathrm{~min}$, and then rise to $220^{\circ} \mathrm{C}$ with the rate of $20^{\circ} \mathrm{C} / \mathrm{min}, 220^{\circ} \mathrm{C}$ for $1 \mathrm{~min}$, further increased to $240^{\circ} \mathrm{C}$ with the rate of $20^{\circ} \mathrm{C} / \mathrm{min}$, finally maintained at $240^{\circ} \mathrm{C}$ for $5 \mathrm{~min}$. The soluble carbohydrate was analyzed using anthrone-sulfuric acid method with glucose as standard [6], and the soluble protein was analyzed by Lowry method [7]. The samples for analysis of soluble carbohydrate and protein were filtrated by $0.45 \mu \mathrm{m}$ membrane before detecting. TS, VS and $\mathrm{NH}_{4}^{+}-\mathrm{N}$ were determined according to Standard Methods [8].

\subsection{Calculation for cumulative methane production}

In the batch experiment, the cumulative methane production was calculated described as the equation (1) [9].

$$
V_{2}=V_{1}+V_{G} \cdot C_{2}+V_{0} \cdot\left(C_{2} \cdot C_{1}\right)
$$

Where $V_{1}, V_{2}$ represents the methane production $(\mathrm{ml})$ at the time of $t_{1}$ and $t_{2}$, respectively; $C_{1}, C_{2}$ the methane content in the gas space of anaerobic bottle (\%) at the time of $t_{1}$ and $t_{2}$, respectively; $V_{0}$ the volume of the gas space of anaerobic bottle $(\mathrm{ml}) ; V_{\mathrm{G}}$ the produced biogas $(\mathrm{ml})$ during the time gap between $t_{1}$ and $t_{2}$.

\subsection{Kinetic analysis}

The cumulative methane volume in batch experiments followed the modified Gompertz equation [10], as shown in Equation (2).

$$
H=P \cdot \exp \left\{-\exp \left[\frac{R_{m} \cdot e}{P}(\lambda-t)+1\right]\right\}
$$

where $H$ represents the cumulative methane production $(\mathrm{ml})$, the lag phase time $(\mathrm{h}), P$ the methane production potential (ml), and $R_{\mathrm{m}}$ the maximum methane production rate $(\mathrm{ml} / \mathrm{h})$. The values of $P, R_{\mathrm{m}}$ and $\lambda$ were determined by best fitting the methane production data for Eq. (2) using Microsoft's software Excel 2010.

\subsection{Calculation for VS removal efficiency}

The VS removal efficiency in the overall fermentation process was calculated according to the equation (3), as following.

$$
R E=\left(V S_{\mathrm{f}}+V S_{\mathrm{S} 1}+V S_{\mathrm{S} 2}-V S_{\mathrm{e}}\right) /\left(V S_{\mathrm{f}}+V S_{\mathrm{S} 1}+V S_{\mathrm{S} 2}\right)
$$

Where $R E$ represent the VS removal efficiencies in the whole process, respectively (\%). $V S_{\mathrm{f}}, V S_{\mathrm{S} 1}$ and $V S_{\mathrm{S} 2}$ were defined as the VS of initial feedstock, preacidification and methane-producing seed sludge (g). $V S_{\mathrm{e}}$ was the VS at the end of methane production $(\mathrm{g})$.

\section{Results and Discussion}

\subsection{Characteristic of chicken manure}

The main component was shown in Table 1. Table 1 suggested that chicken manure contained $25.64 \%$ of TS in wet weight (ww) and $59.28 \%$ of TS was organic matters. The $\mathrm{NH}_{4}{ }^{+}-\mathrm{N}$ concentration was as high as 11.32 $\mathrm{mg} / \mathrm{g}$-ww in this study, which might be caused by the degradation of nitrogen-contain materials during the storage of chicken manure. Table 1 also shows that the sum of total carbohydrate and total protein account for $16.5 \%$ of VS, suggesting that great amount of other organic matters in chicken manure were not detected. The soluble component that was easily to be utilized by microorganisms was also measured. However, results 
show only $4.5 \%$ and $5.7 \%$ of total carbohydrate and protein were soluble, implying the chicken manure was hard to be hydrolyzed to some extent.

Table 1. Component of Chicken Manure based on wet weight (ww).

\begin{tabular}{|c|c|c|}
\hline Program & Unit & Value \\
\hline $\begin{array}{c}\text { Total } \\
\text { carbohydrate }\end{array}$ & $\mathrm{mg} / \mathrm{g}$-ww & 18.0 \\
\hline $\begin{array}{c}\text { Soluble } \\
\text { carbohyrate }\end{array}$ & $\mathrm{mg} / \mathrm{g}$-ww & 0.81 \\
\hline $\begin{array}{c}\text { Total protein } \\
\text { Soluble } \\
\text { protein }\end{array}$ & $\mathrm{mg} / \mathrm{g}$-ww & 7.17 \\
\hline $\begin{array}{c}\mathrm{NH}{ }_{4}{ }^{+}-\mathrm{N} \\
\mathrm{TS}\end{array}$ & $\mathrm{mg} / \mathrm{g}-\mathrm{ww}$ & 0.4 \\
\hline $\mathrm{VS}$ & $\%$ & 25.64 \\
\hline $\mathrm{VS} / \mathrm{TS}$ & $\%$ & 59.28 \\
\hline
\end{tabular}

\subsection{VFAs produced in pre-acidification stage}

The pre-acidification stage was performed for nearly three days. The VFAs including acetate, propionate, butyrate, i-butyrate, i-valerate were detectable in the digestate after pre-acidification stage, as shown in Figure 1. Due to the hydrolysis and acidification of the organic matters, a sum of $1588 \mathrm{mg}-\mathrm{VFAs} / \mathrm{l}$ was produced in the end of pre-acidification stage. The acetate was the dominant among all kinds of VFAs, accounting for $68 \%$ of the total amount. The acetate could be directly utilized by the pathway of aceticlastic methanogenesis, which was the main pathway for Methanosarcina, Methanosaeta, and etc [11]. Followed by acetate, the propionate with the percentage of $19 \%$ was the second main component, which was not popular with methanogens and would inhibit the methanogens activity under the high concentrations.

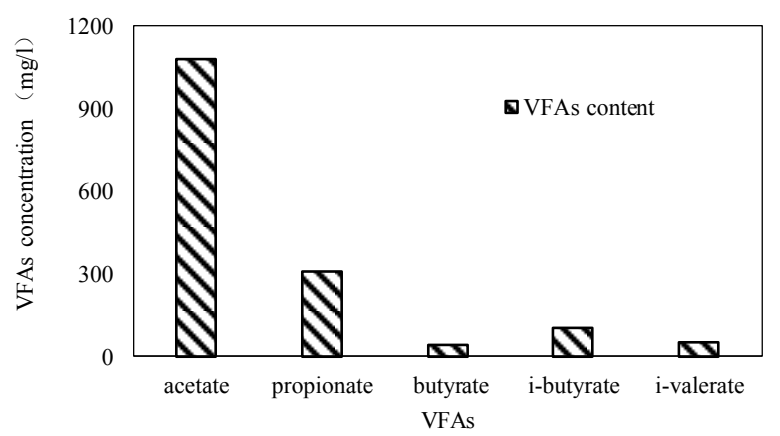

Fig. 1. VFAs component detected in the digestate in the end of pre-acidification stage.

\subsection{Biogas production and methane content in methane production stage}

After pre-acidification stage, the methane-producing seed was added into the anaerobic bottles, and $\mathrm{pH}$ was adjusted to 7.0, which is suitable for methane fermentation. The phosphate buffered saline was benefit for $\mathrm{pH}$ maintenance and the $\mathrm{pH}$ was 6.8-7.0 during the whole fermentation process. The daily biogas production and methane content in methane production stage was shown in Figure 2.

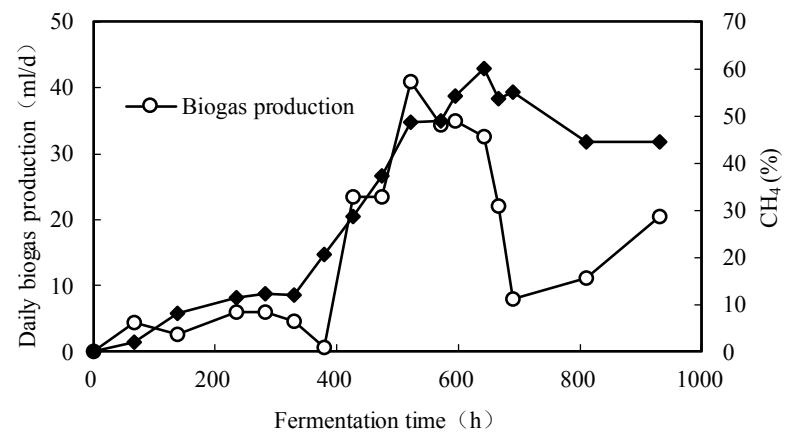

Fig. 2. The daily biogas production and methane content in biogas during the methane production stage.

As shown in Figure 2, the daily biogas production had experienced three peak periods during the total fermentation time of $930 \mathrm{~h}$. In the first peak period $(0-$ $378.5 \mathrm{~h}$ ), the daily biogas production was lower than 6 $\mathrm{ml}$ and even reduced to $1 \mathrm{ml}$ at $378.5 \mathrm{~h}$, but the methane content increased smoothly to $20.7 \%$. It could be speculated that a large percentage of the biogas produced by the biochemical reactions must be methane in the first peak period. In the second peak period (378.5-666.5 h), the daily biogas production increased greatly with the highest value of $40.8 \mathrm{ml} / \mathrm{d}$ and the average value of 32.9 $\mathrm{ml} / \mathrm{d}$. The methane content increased sharply to $60 \%$ with the increase rate of $3.3 \mathrm{ml} / \mathrm{d}$. After the rapid increase stage, the daily biogas production slowly increased to $20.4 \mathrm{ml} / \mathrm{d}$ during the final peak period $(666.5-930.5 \mathrm{~h})$ and the methane content was slightly decreased to $44.5 \%$. The tendency of the biogas production curve with three peak period during methane production stage might be caused by the insufficient of direct substrates for methanogens and the inhibition of metabolic products on the microorganisms.

\subsection{Kinetic fitting of the cumulative methane production}

Figure 3 shows the cumulative methane production calculated by Equation (1) by chicken manure digestion and the corresponding curves of Equation (2) using the best-fitted kinetic parameters. The results showed that the values of $P, R_{\mathrm{m}}$ and $\lambda$ were $345.2 \mathrm{ml}, 0.948 \mathrm{ml} / \mathrm{h}$ and $343.5 \mathrm{~h}$, respectively. 


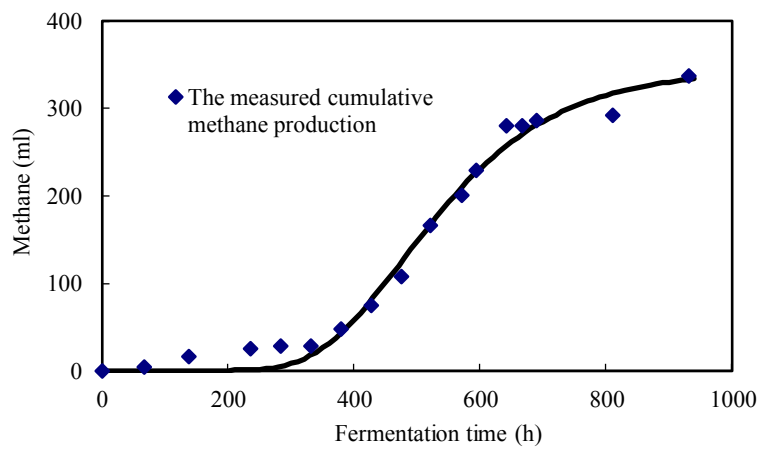

Fig. 3. The cumulative methane production in the methane production stage.

\subsection{VS removal efficiency and methane yield}

The VS removal efficiency during the whole fermentation process calculated according to equation (3) reached a value of $52.7 \%$, implying that nearly half of the organic matters were converted into biogas. The methane yield was calculated through dividing the produced cumulative methane by the removed VS, and the value was $183 \mathrm{ml}-\mathrm{CH}_{4} / \mathrm{g}-\mathrm{VS}_{\text {removed }}$.

\section{Conclusion}

The two-stage anaerobic digestion process with separated pre-acidification and methane production was applied in chicken manure treatment. Batch experiment results shows that the VFAs was produced in the preacidification stage with a total amount of $1588 \mathrm{mg}$ VFAs/ 1 and the acetate was the main component. The methane yield reached $183 \mathrm{ml}-\mathrm{CH}_{4} / \mathrm{g}-\mathrm{VS}_{\text {removed }}$ during the methane production stage and VS removal efficiency was $52.7 \%$ for the whole fermentation process.
Authors wishing to acknowledge the financial support by the Tianjin Research Program of Application Foundation and Advanced Technology, China (Program No.16JCQNJC08200) and the National Natural Science Funds for Distinguished Young Scholar of China (No. 21607114).

\section{References}

1. Y. Wang. China swine ind., 4 (2014)

2. J. Cao, B. Wu. Guangdong Feed, 26, 11 (2017)

3. Decree of the State Council NO.643, Regulations on the prevention and control of pollution by livestock and poultry. (Decree of the State Council, Beijing, 2013)

4. H. Tian, N. Duan, C. Lin, et al. J. Biosci. Bioeng. 120, 1 (2015)

5. C. Sun, W. Cao, C.J. Banks, et al. Bioresour. Technol. 218 (2016)

6. A. F. Gaudy. Industrial Water Wastes, 7, (1962)

7. O.H. Lowery, N.J. Rosebrough, A.L. Farr, et al. J. Biol. Chem. 193 (1951)

8. APHA. Standard Methods for the Examination of Water and Wastewater, 21st ed. (APHA, Washington DC, 2005)

9. T. Zhang. Improved study on anaerobic fermentation of sewage sludge for volatile fatty acids by pretreatment with ultrasonic coupling technology. (Suzhou University of Science and Technology, Suzhou, Jiangsu, China, 2015)

10. J.J. Lay, Y.Y. Li, T. Noike. J. Environ. Eng. 124, (1998)

11. J.L. Garcia, B.K.C. Patel, B. Ollivier. Anaerobe, 6, (2000)

\section{Acknowledgments}

